\title{
Pengembangan Media ICT Berbasis Chemoedutainment Berupa Chemblocks Games Untuk Memfasilitasi Pembelajaran di Masa Pandemi COVID-19
}

\section{The Development of ICT Media Based on ChemoEdutainment Chemblock Games to Facilitate Learning Process in Pandemic Era COVID-19}

\author{
N Puspitaningrum ${ }^{1 *}$, M Ramli ${ }^{1}$, and L Yunita ${ }^{1}$ \\ ${ }^{1}$ Pendidikan Kimia, Fakultas Ilmu Tarbiyah dan Keguruan, \\ UIN Syarif Hidayatullah Jakarta, Jakarta, Indonesia. 15412 \\ *nillam.puspitaningrum16@mhs.uinjkt.ac.id
}

\section{ARTICLE INFO \\ Received on: \\ 17 September 2021 \\ Revised till: \\ 27 October 2021 \\ Accepted on: \\ 21 November 2021 \\ Publisher version published on: \\ 25 November 2021}

\begin{abstract}
This study aims to produce an educational game application called Chemblocks Games based on chemoedutainment on chemical bonding materials. The subjects in this study were expert validators, teachers and students. This study uses the TSRD model $R$ \& $D$ method, which consists of the following stages: Pre development, Development, and Post Development. The instruments used are a mix of teacher needs analysis interviews, student needs analysis questionnaires, validation sheets and teacher and student response questionnaires. Validation data processing techniques and response questionnaires use a Likert scale. Data analysis was carried out by converting the results of the Likert scale points into percentages. Chemblocks Games received an assessment from material experts of $88.61 \%$, media experts of $83.5 \%$ and teacher participant test assessments of $94 \%$. So the Chemblocks Games product is in the "very decent" category. Based on the results of the student response questionnaire in the limited test, the percentage obtained was $84.5 \%$ in the material aspect, $86.5 \%$ in the language aspect, and $87 \%$ in the attractiveness aspect. So the student's response to the Chemblocks games application is in the "Very Good" category.
\end{abstract}

\section{KEYWORDS}

Chemblocks Games, Chemical Bonding, Chemoedutainment, ICT Learning Media, TSRD

\section{ABSTRAK}

Penelitian ini bertujuan untuk menghasilkan aplikasi game edukasi bernama Chemblocks Games berbasis Chemoedutainment pada materi ikatan kimia. Subjek pada penelitian ini adalah validator ahli, guru dan siswa. Penelitian ini menggunakan metode R\&D model TSRD yang terdiri dari tahap: Pra Development, Development, dan Post Development. Instrumen yang digunakan adalah paduan wawancara analisis kebutuhan guru, angket analisis kebutuhan siswa, lembar validasi dan angket respons guru dan siswa. Teknik pengolahan data validasi dan angket respons menggunakan skala likert. Analisis data dilakukan dengan mengubah hasil poin skala likert menjadi persentase. Chemblocks Games mendapatkan penilaian dari ahli materi sebesar $88,61 \%$, ahli media sebesar $83,5 \%$ dan penilaian uji partisipan guru sebesar 94\%. Sehingga produk Chemblocks Games berada pada kategori "Sangat layak". Berdasarkan hasil angket respons siswa pada uji terbatas diperoleh persentase sebesar $84,5 \%$ pada aspek materi, $86,5 \%$ pada aspek bahasa, dan $87 \%$ pada aspek kemenarikan. Sehingga respons siswa terhadap aplikasi chemblocks games dalam kategori "Sangat Baik”.

KATA KUNCI

Chemblocks Games, Chemoedutainment, Ikatan Kimia, Media Pembelajaran ICT, TSRD 


\section{PENDAHULUAN}

Kurikulum 2013 menekankan pembelajaran aktif yang berpusat pada siswa ${ }^{[1]}$. Namun pada kenyataannya, berdasarkan hasil observasi saat melaksanakan PLP 1, masih terdapat proses pembelajaran yang berpusat pada guru dengan menggunakan metode ceramah. Metode ini seringkali menciptakan rasa kebosanan pada siswa. Salah satu penyebab kesulitan belajar yang dialami peserta didik dikarenakan peserta didik tidak mau mendengarkan materi yang disampaikan guru dan merasa jika cara mengajar guru membosankan ${ }^{[2]}$. Terdapat keterkaitan antara tingkat keaktifan dan motivasi belajar siswa terhadap ketercapaian tujuan pembelajaran. Siswa dengan keaktifan dan motivasi belajar yang tinggi lebih dapat memahami materi dan mencapai tujuan pembelajaran. Sehingga pembelajaran yang tidak menyenangkan dapat menyebabkan pembelajaran menjadi kurang berkualitas ${ }^{[3]}$.

Salah satu faktor yang menyebabkan rendahnya kualitas pembelajaran adalah kurang tersedianya media pembelajaran. Sehingga dalam proses pembelajaran yang berlangsung tidak difasilitasi dengan media pembelajaran. Media pembelajaran yang sangat dibutuhkan saat ini adalah media pembelajaran ICT, dikarenakan saat ini peserta didik hidup berdampingan dengan teknologi yang canggih, seperti: laptop, tablet dan handphone. Manusia terus belajar dan berinteraksi setiap hari menggunakan teknologi informasi dan komunikasi $^{[4]}$. Hal ini juga didukung oleh adanya revolusi industri 4.0 dimana teknologi mulai digunakan untuk seluruh kegiatan, sehingga semua telah beralih ke arah digital.

Saat pandemi COVID-19 yang mengharuskan pembelajaran dilakukan secara jarak jauh juga sangat bergantung dengan teknologi dalam proses pembelajarannya. Hal ini menuntut guru dan siswa untuk menggunakan media pembelajaran ICT seperti multimedia pembelajaran dalam proses pembelajaran. Salah satu kelebihan dari multimedia pembelajaran adalah memiliki nilai fleksibilitas yaitu dapat digunakan dimana saja dan kapan saja sehingga penggunaannya tidak terpaku hanya di sekolah. Namun ketersediaan media pembelajaran ICT masih kurang sehingga umumnya guru terpaku dengan penggunaan media powerpoint dalam proses pembelajaran daring. Sehingga media yang digunakan dalam pembelajaran daring masih terbatas dan kurang bervariasi.

Game edukasi merupakan salah satu jenis multimedia pembelajaran yang paling diminati oleh siswa. Berdasarkan hasil analisis kebutuhan dihasilkan terdapat $80 \%$ siswa yang menyukai bermain game di handphone. Game dapat menjadi sarana hiburan bagi siswa namun game juga memiliki dampak negatif yang akan membuat siswa kecanduan terlebih saat ini banyak sekali beredar game online yang tidak memiliki nilai pengetahuan. Kecanduan game online dapat berdampak buruk pada beberapa aspek kehidupan seperti aspek akademik, aspek psikologis, aspek sosial, dan sebagainya ${ }^{[5]}$. Dimana semakin banyak waktu yang dihabiskan oleh siswa untuk bermain game maka semakin rendah motivasi belajarnya ${ }^{[6]}$. Game edukasi merupakan media pembelajaran yang menggabungkan nilai pengetahuan dan hiburan. Pembelajaran yang dikemas dalam permainan diharapkan dapat meningkat motivasi belajar siswa. Hal ini dikarenakan berdasarkan hasil analisis kebutuhan terdapat $75 \%$ responden siswa yang kurang menyukai mata pelajaran kimia. Pada saat melakukan analisis kebutuhan, materi yang sedang berlangsung saat itu adalah materi ikatan kimia, dan menunjukkan hasil $85 \%$ responden siswa mengalami kesulitan dalam materi ikatan kimia.

Chemoedutainment merupakan metode pembelajaran kimia yang umumnya menggunakan permainan dalam proses pembelajarannya. Pembelajaran berorientasi chemoedutainment dengan bantuan media permainan edukasi dapat meningkatkan ketertarikan siswa, rasa ingin tahu, pemahaman serta motivasi siswa terhadap materi yang sedang dipelajari ${ }^{[7]}$. Proses pembelajaran dengan model permainan memiliki potensi yang tinggi dalam meningkatkan motivasi belajar siswa, memudahkan siswa dalam memahami materi yang sulit, menciptakan suasana menyenangkan sehingga tidak menimbulkan rasa bosan saat pembelajaran berlangsung, dan lebih mudah mengingat informasi karena adanya bantuan media pembelajaran ${ }^{[8]}$.

Chemblocks games merupakan game edukasi yang mengadopsi prinsip make a match dan petualangan. permainan dengan konsep make a match dapat menumbuhkan proses berpikir tingkat tinggi siswa. Karena siswa dituntut untuk mencari pasangan yang cocok sehingga dibutuhkan pemahaman konsep yang baik ${ }^{[9]}$. Sebagian besar siswa mengalami kesulitan belajar pada materi ikatan kimia sehingga penulis tertarik untuk mengembangkan chemblocks games berbasis chemoedutainment pada materi ikatan kimia.

\section{METODE}

Penelitian ini dilaksanakan pada bulan September 2020 - Mei 2021 di SMAN 1 Kota Tangerang Selatan dan SMAN 6 Kota Tangerang Selatan. Objek dari penelitian ini adalah Chemblocks Games dan Subjek dari penelitian ini adalah dosen validator, guru kimia, dan siswa. Metode penelitian yang digunakan dalam mengembangkan Chemblocks Games berbasis Chemoedutainment adalah metode Research and Development (R\&D). Research and Development adalah metode penelitian yang bertujuan untuk menghasilkan produk-produk tertentu serta menguji validitas dari produk yang dikembangkan ${ }^{[10]}$.

Model yang digunakan dari penelitian pengembangan ini adalah model TSRD (three stages research and development). TSRD merupakan model pengembangan yang didesain untuk pemula seperti mahasiswa tingkat akhir atau guru baru ${ }^{[11]}$. TSRD terdiri dari 3 tahap sebagai berikut : (1) Pra development, tahap ini merupakan 
tahap awal pengembangan yang bertujuan untuk mengemukakan masalah, menganalisis kebutuhan, menganalisis materi serta membentuk rancang bangun awal. Pra development terdiri dari 4 tahapan sebagai berikut: (a) Analisis kebutuhan guru dan siswa; (b) Analisis Materi; (c) Pembuatan desain awal produk berupa storyboard; (d) Validasi Storyboard kepada ahli materi. (2) Development, Tahap ini bertujuan untuk mengembangkan rancang bangun awal menjadi produk jadi yang tervalidasi ahli. Development terdiri dari 5 tahapan sebagai berikut: (a) pengembangan produk; (b) validasi materi; (c) validasi media; (d) uji partisipan guru; (e) uji terbatas siswa. (3) Post development, tahap ini bertujuan untuk menyebarluaskan hasil penelitian dapat berupa naskah skripsi, artikel, ataupun produk yang telah dikembangkan ${ }^{[11]}$.

Instrumen yang digunakan berupa panduan wawancara analisis kebutuhan guru, Angket analisis kebutuhan siswa, lembar validasi materi, lembar validasi media, angket respons guru, dan angket respons siswa. Teknik pengolahan data yang digunakan adalah skala likert. Teknik analisis data yang digunakan adalah dengan mengubah poin hasil menjadi dalam bentuk persentase, menggunakan rumus pada Persamaan $1^{[12]}$.

$$
\text { Persentase }=\frac{\text { skor total }}{\text { skor maksimal }} \times 100 \% \ldots \text { Persamaan } 1 .
$$

Hasil persentase ini selanjutnya diinterpretasikan sesuai kategorinya. Tingkat validitas didasarkan pada kriteria yang disajikan pada Tabel 1 .

Tabel 1. Kriteria Validasi ${ }^{[12]}$.

\begin{tabular}{c|c|c}
$\begin{array}{c}\text { Tingkat } \\
\text { Pencapaian }\end{array}$ & Kualifikasi & Keterangan \\
\hline $81 \%-100 \%$ & Sangat layak & Tidak perlu revisi \\
\hline $60 \%-80 \%$ & Layak & Tidak perlu revisi \\
\hline $41 \%-60 \%$ & Cukup layak & Perlu revisi \\
\hline $21 \%-40 \%$ & Kurang layak & Perlu revisi \\
\hline $0 \%-20 \%$ & Tidak layak & Revisi total
\end{tabular}

Tingkat respons siswa dan guru didasarkan pada kriteria yang disajikan pada Tabel $2^{[13]}$.

Tabel 2. Kriteria Interpretasi Skor Respons.

\begin{tabular}{c|c} 
Tingkat Pencapaian & Kualifikasi \\
\hline $81 \%-100 \%$ & Sangat Baik \\
\hline $60 \%-80 \%$ & Baik \\
\hline $41 \%-60 \%$ & Cukup Baik \\
\hline $21 \%-40 \%$ & Kurang Baik \\
\hline $0 \%-20 \%$ & Tidak Baik
\end{tabular}

\section{HASIL DAN DISKUSI}

\subsection{Pra Development}

\subsubsection{Analisis kebutuhan}

Berdasarkan hasil analisis kebutuhan diketahui bahwa minat belajar kimia siswa masih tergolong rendah dan sebagian besar responden siswa mengalami kesulitan belajar pada materi ikatan kimia. Untuk mengatasi hal ini penggunaan media pembelajaran dapat menjadi salah satu solusinya. Menurut hasil wawancara dengan guru kimia, dikatakan bahwa minat belajar dan antusiasme siswa meningkat ketika proses pembelajaran menggunakan media pembelajaran yang menarik seperti aplikasi game edukasi, namun penggunaan media pembelajaran ini masih terkendala oleh kurang tersedianya media pembelajaran untuk semua materi kimia. Sehingga media yang digunakan dalam proses pembelajaran di sekolah masih kurang bervariasi. Sering kali media yang digunakan guru terpaku pada powerpoint dan video pembelajaran dari YouTube. Sehingga media pembelajaran berupa aplikasi Chemblocks Games dibutuhkan oleh guru maupun siswa untuk menunjang pembelajaran.

\subsubsection{Analisis Materi}

Berdasarkan hasil analisis KD 3.5 ditemukan beberapa poin besar sub materi yang akan menjadi indikator pembelajaran seperti: kestabilan unsur, jenis-jenis ikatan kimia, proses terbentuknya ikatan kimia, serta sifat fisik dari ikatan kimia.

\subsubsection{Desain Storyboard}

Storyboard merupakan rancang bangun awal dari aplikasi Chemblocks Games. Desain Storyboard dibuat dengan menggunakan Adobe Illustrator dan Photoshop. Terdapat 4 bagian utama storyboard: (1) bagian pembuka dan informasi, (2) bagian ringkasan materi, (3) bagian permainan dan (4) bagian penutup. Selain storyboard pada tahap ini juga dibentuk flowchart sebagai kerangka awal media yang akan dikembangkan. Flowchart ini dapat dilihat pada Gambar 1. Untuk permainan make a match dalam chemblocks games ini dapat dilihat pada Gambar 2.

\subsubsection{Validasi Storyboard}

Storyboard divalidasi oleh 2 dosen ahli materi untuk mengetahui kelayakan dan kesesuaian konten kimia yang terdapat pada storyboard. Hasil dari validasi storyboard didapatkan persentase ratarata sebesar 83,20\% dengan kategori "sangat layak".

\subsection{Development}

\subsubsection{Pengembangan Produk}

Rancangbangunawal berupa storyboard yangtelah tervalidasi selanjutnya dikembangkan menggunakan software Construct 2. Construct 2 merupakan game engine berbasis HTML5 yang dikembangkan oleh Scirra Ltd. Construct 2 memiliki kelebihan mempermudah pengembang game untuk membuat aplikasi dengan metode visual programming, yaitu drag \& drop modul yang telah disediakan dengan kebutuhan coding yang 
Edukimia • 2021 • Vol. 3, No. 3

minimal, dengan adanya tools Construct 2 dapat memudahkan proses pembuatan game $e^{[14]}$. Produk yang dihasilkan berupa aplikasi Chemblocks Games berukuran
$58 \mathrm{MB}$ yang dapat digunakan pada smartphone Android dengan OS 6 ke atas. Selain itu aplikasi ini juga dapat diinstall pada laptop Windows 32 bit dan 64 bit.

\section{Flowchart dari Chemblock Games}

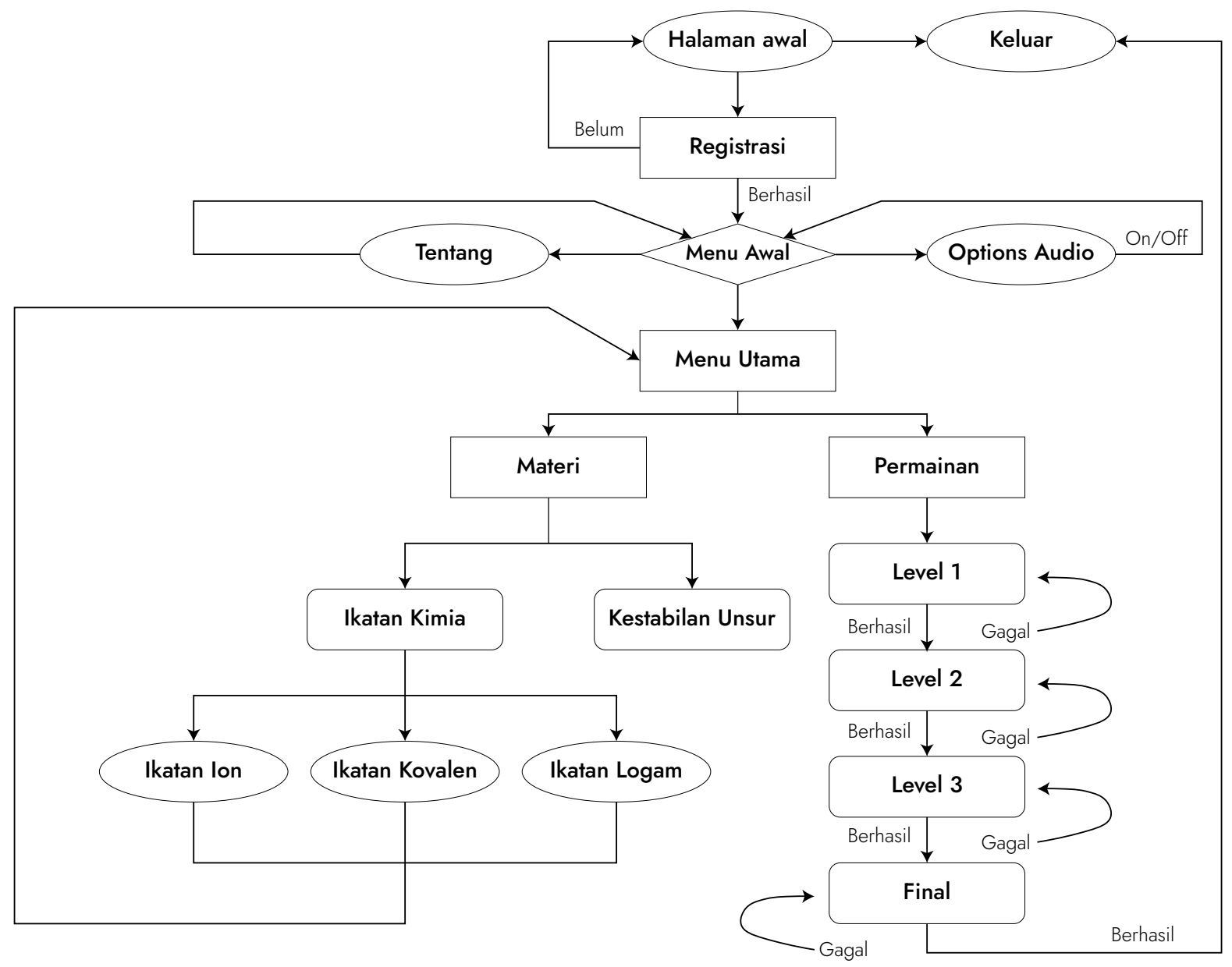

Gambar 1. Flowchart Chemblocks Games.
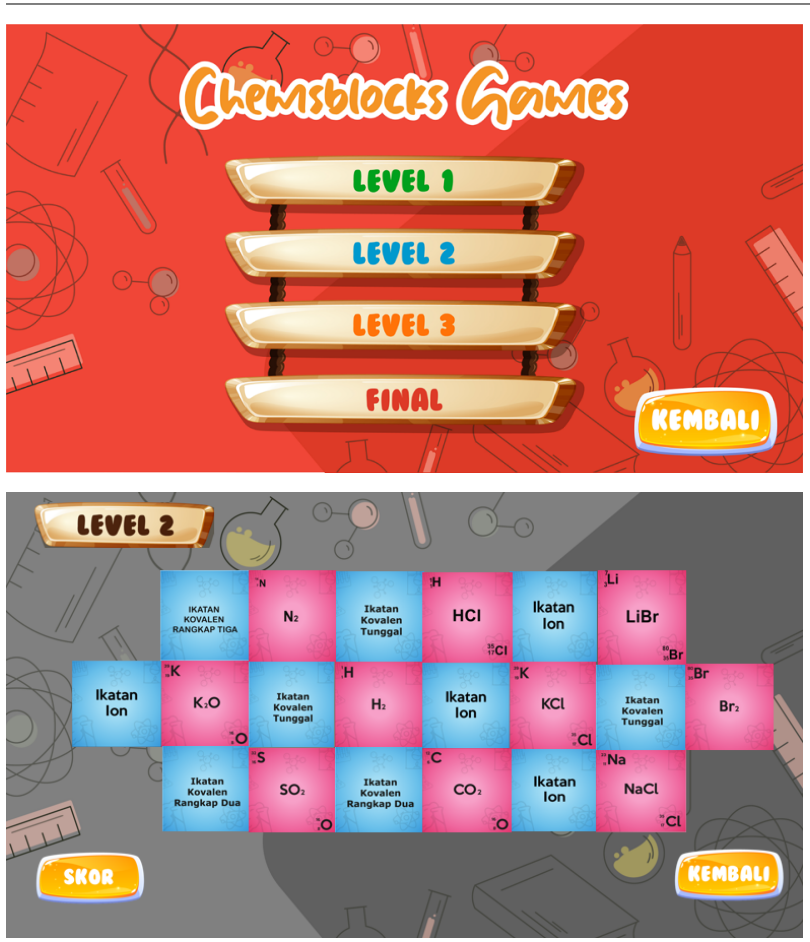
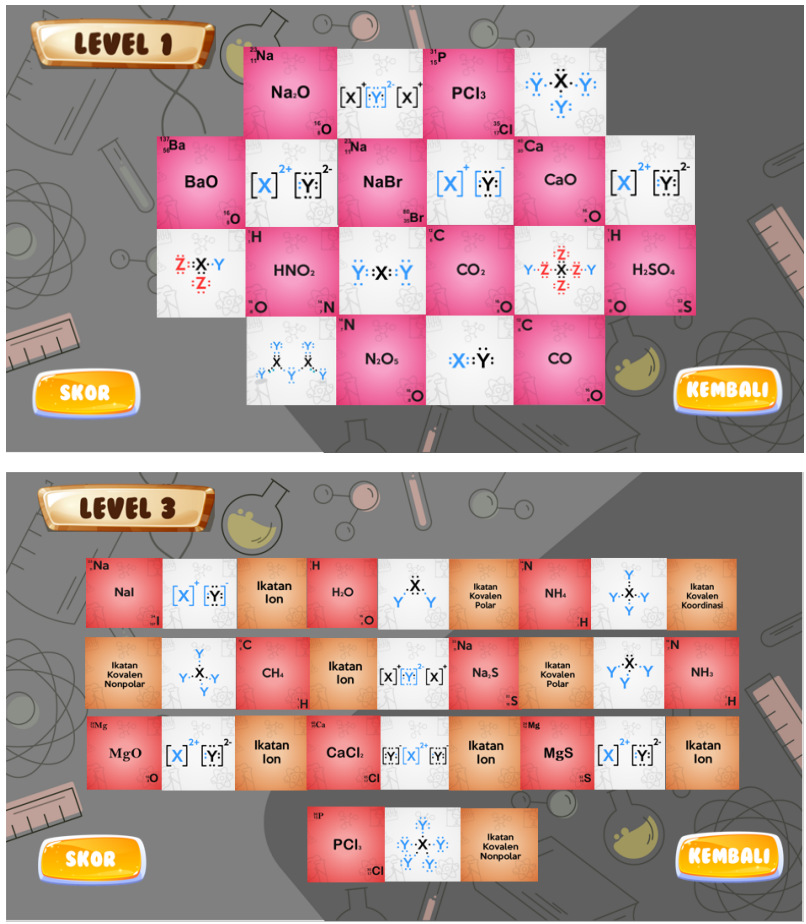

Gambar 2. Chemblocks Games. 
Android merupakan sistem operasi yang dirancang untuk perangkat seluler layar sentuh seperti smartphone dan tablet. Android memiliki manfaat dalam bidang pendidikan, dimana saat ini telah banyak berkembang aplikasi pendidikan yang terdapat di Play Store. Kelebihan dari sistem android adalah user friendly yaitu sangat mudah untuk digunakan, lebih murah dari iOS, dan memiliki konsep open source, yaitu pengguna diberikan kebebasan untuk mengembangkan sistem android miliknya sendiri ${ }^{[15]}$. Pemilihan aplikasi berbasis android Dikarenakan android merupakan sistem yang banyak digunakan pada handphone yang beredar di masyarakat khususnya di kalangan pelajar. Selain itu aplikasi yang digunakan untuk membuat aplikasi game edukasi umumnya men-support sistem android.

\subsubsection{Validasi Materi}

Validasi materi dilakukan oleh 2 dosen ahli materi dengan menggunakan instrumen angket validasi materi yang terdiri dari 3 aspek penilaian yaitu aspek paduan dan informasi untuk menilai kelengkapan dan ketepatan paduan informasi yang diberikan untuk pengguna, aspek materi untuk menilai kualitas materi yang terdapat dalam produk berupa kelengkapan dan ketepatan susunan materi, dan aspek evaluasi untuk menilai kualitas soal atau tantangan yang diberikan pada produk untuk pengguna ${ }^{[16]}$. Informasi ini dapat dilihat pada Gambar 3.

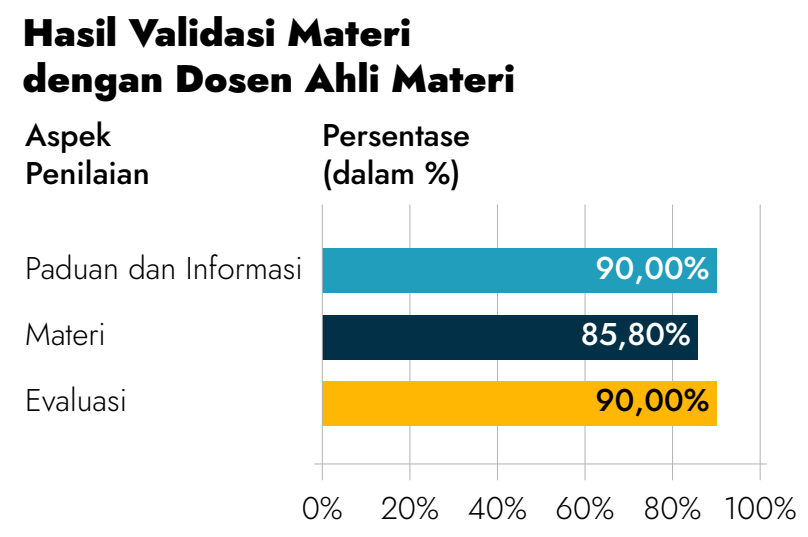

Gambar 3. Hasil Validasi Materi.

Berdasarkan persentase tersebut aspek paduan informasi dan aspek evaluasi mendapatkan persentase tertinggi hal ini dikarenakan pada aplikasi Chemblocks Games diberikan informasi lengkap mengenai identitas pengembang, aturan permainan, dan tujuan pembelajaran. Selain itu evaluasi pembelajaran ikatan kimia pada aplikasi Chemblocks Games dikemas dalam bentuk permainan yang menghibur yang terdiri dari 4 tahapan berupa level 1 , level 2, level 3, dan final yang disusun sedemikian rupa lengkap sesuai dengan tidak kesukaran.

Aspek materi mendapatkan persentase 4,5\% lebih rendah dikarenakan materi yang terdapat pada aplikasi Chemblocks Games merupakan sebuah ringkasan materi untuk review sebelum memulai permainan sehingga tidak terlalu detail. Rangkuman dari materi yang disajikan akan membantu anak didik memahami pokok-pokok isi pembelajaran, apakah berupa konsep, prosedur, atau prinsip. Pemberian rangkuman sangat penting dalam mengingat ide-ide pokok dari materi yang disajikan, sehingga mencegah timbulnya ketidak ingatan dan mengurangi kesulitan-kesulitan yang dialami anak didik dalam mengingat seluruh isi teks ${ }^{[17]}$. Secara keseluruhan hasil dari validasi materi yang terdapat pada aplikasi Chemblocks Games dalam kategori "Sangat Layak" untuk dapat digunakan.

\subsubsection{Validasi Media}

Validasi media dilakukan oleh 2 dosen ahli media dengan menggunakan instrumen angket validasi materi yang terdiri dari 7 aspek penilaian, yaitu: (1) Aspek paduan dan informasi; (2) aspek kinerja program; (3) aspek sistematika; (4) aspek estetika; (5) aspek kualitas narasi dan video; (6) aspek kualitas video dan animasi; serta (7) aspek reka bentuk multimedia ${ }^{[16]}$. Informasi ini dapat dilihat pada Gambar 4. Berdasarkan persentase tersebut maka kualitas media yang terdapat pada aplikasi Chemblocks Games dalam kategori "Sangat Layak" untuk dapat digunakan.

\section{Hasil Validasi Media dengan Dosen Ahli Media}

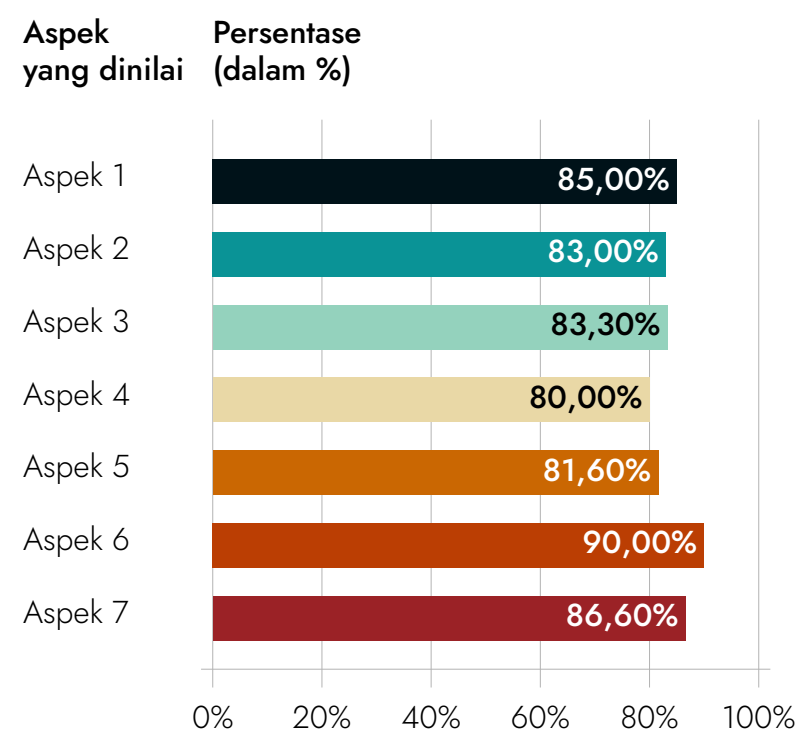

Gambar 4. Hasil Validasi Media.

\subsubsection{Uji Partisipan Guru}

Uji partisipan guru bertujuan untuk mengetahui apakah kesesuaian media yang dikembangkan dengan kebutuhan. Responden uji partisipan guru adalah 2 guru kimia yang sebelumnya telah menjadi responden di tahap analisis kebutuhan. Instrumen yang digunakan merupakan angket respons guru yang terdiri dari 3 aspek. Informasi ini dapat dilihat pada Gambar 5.

Berdasarkan persentase tersebut maka aplikasi Chemblocks Games dalam kategori "Sangat baik" menurut responden guru kimia, dimana Chemblocks 


\section{Hasil Uji dengan Partisipan Guru (dalam persen)}
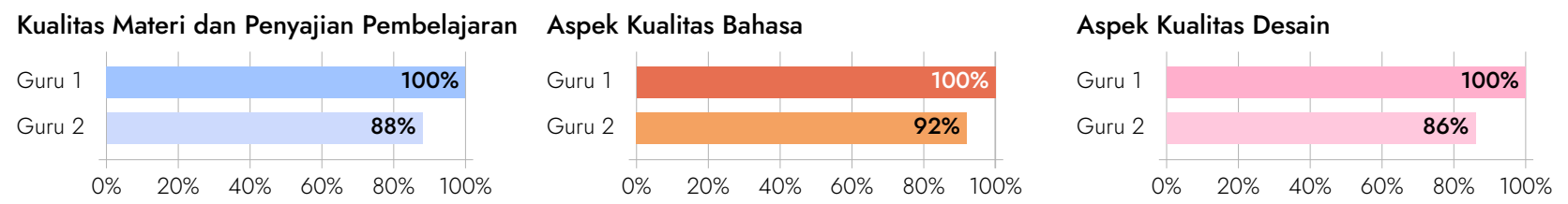

Gambar 5. Hasil Uji Partisipan Guru.

Games telah sesuai dengan apa yang dibutuhkan dalam menunjang proses pembelajaran.

\subsubsection{Uji terbatas}

Uji terbatas dilakukan di kelas X-IPA 4 SMAN 1 Kota Tangerang selatan yang berjumlah 40 orang. Instrumen yang digunakan pada uji terdatas siswa adalah angket respons siswa yang terdiri dari 3 aspek penilaian. Hasil dari uji terbatas ini dapat dilihat pada Gambar 6.

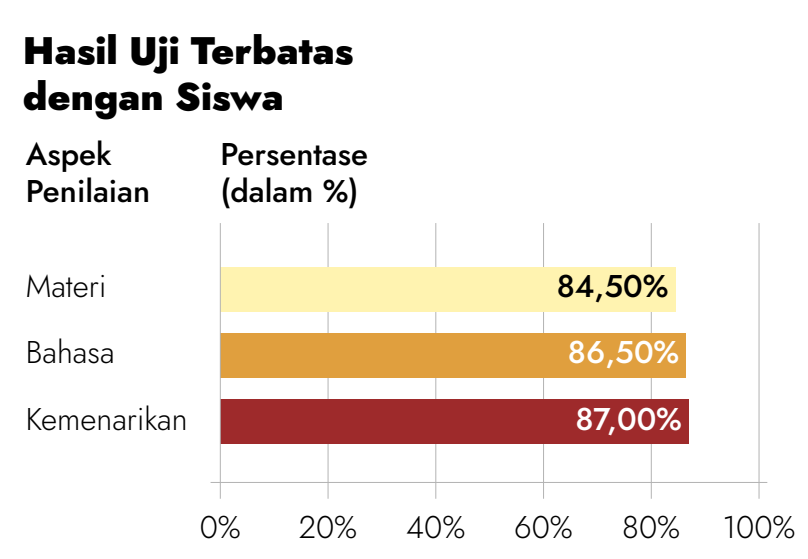

Gambar 6. Hasil Uji Terbatas.

Berdasarkan respons siswa Chemblocks Games membuat pembelajaran ikatan kimia menjadi menyenangkan dengan perolehan persentase terbesar yaitu $89,5 \%$. Dimana materi dan tantangan yang terdapat di Chemblocks games meningkatkan rasa penasaran siswa dengan perolehan persentase sebesar $83 \%$. Hal ini sesuai dengan penelitian yang menyatakan bahwa media yang menarik dapat mendorong rasa ketertarikan siswa untuk lebih memperhatikan materi yang sedang dipelajari ${ }^{188}$. Selanjutnya akan berdampak pada meningkatnya minat belajar siswa, dengan persentase sebesar $86 \%$. Hal ini sesuai penelitian yang menyatakan bawa multimedia interaktif game dapat meningkatkan motivasi meningkatkan minat dan semangat belajar siswa ${ }^{[19]}$. Secara keseluruhan hasil uji terbatas siswa menyatakan bahwa aplikasi Chemblocks Games dalam kategori "Sangat baik" menurut responden siswa.

\subsection{Post Development}

Post development terdiri dari tahap disseminate atau penyebaran. Penyebaran ini bertujuan untuk menyalurkan hasil penelitian. Penyebaran yang dilakukan berupa naskah skripsi, artikel, dan produk Chemblocks Games. Aplikasi Chemblocks games disebar melalui link google drive untuk penginstalan di laptop, dan melalui playstore untuk di-install pada smartphone android. Penyebaran aplikasi Chemblocks Games di Play Store bertujuan agar pengguna lebih mudah dalam menginstall dan tersebar ke masyarakat luas ${ }^{[20]}$.

\section{SIMPULAN}

Media Chemblocks Games pada materi ikatan kimia berbasis Chemoedutainment dikembangkan melalui metode penelitian R\&D dengan model TSRD. Terdapat 3 tahap utama dengan hasil sebagai berikut: 1) Pra development, bahwa pada analisis kebutuhan menunjukan 81\% siswa menginginkan media Chemblocks Games dan 71\% siswa mengalami kesulitan belajar kimia pada materi ikatan kimia. Sehingga dikembangkan media Chemblocks games pada materi ikatan kimia dengan menganalisis KD 3.5. Perancangan media Chemblocks Games menghasilkan storyboard yang telah tervalidasi oleh ahli materi dengan persentase penilaian sebesar $83,2 \%$ dengan kategori "sangat layak" untuk digunakan. 2) Development, Chemblocks Games diproduksi menggunakan software Construct 2, Aplikasi yang dikembangkan merupakan aplikasi berbasis android yang didukung pada android versi 6.0 keatas dengan besar 58 MB. Chemblocks Games mendapatkan penilaian validasi dari ahli materi sebesar $88,61 \%$, ahli media sebesar $83,5 \%$ dan penilaian uji partisipan guru sebesar $94 \%$, serta mendapatkan penilaian uji terbatas respons siswa sebesar $85,93 \%$ dengan hasil tersebut maka Chemblocks Games telah layak digunakan dan mendapatkan respons sangat baik. 3) Post Development, penyebaran dalam penelitian ini berupa penulisan karya skripsi, jurnal, dan penyebaran.

\section{REFERENSI}

1. Afriani N. Pengembangan Lembar Kerja Siswa Berbasis Model Pembelajaran Learning Cycle 7E untuk Memfasilitasi Kemampuan Berpikir Kritis Siswa Sekolah Menengah Atas di Tempuling [Internet]. Universitas Islam Negeri Sultan Syarif Kasim Riau; 2018.

2. Anugraeni PF. Analisis Kesulitan Belajar Mata Pelajaran Ekonomi Kelas Xi Ips Di Sma Muhammadiyah 2 Surakarta Tahun 2018/2019. naskah Publ [Internet]. 2018;

3. Heriyanto A, Haryani S, Sedyawati SMR. Pengembangan Multimedia Pembelajaran Interaktif Berbasis Education Game Sebagai Media Pembelajaran Kimia. Chem Educ [Internet]. 2014;3(1). 
4. Xiao Z, Johnson C, Mcgill M, Bouchard D, Bradshaw MK, Bucheli VA, et al. Game development for computer science education. Proc 2016 ITiCSE Work Gr Reports, ITiCSE 2016. 2016;(July):23-44.

5. Novrialdy E. Kecanduan Game Online pada Remaja: Dampak dan Pencegahannya. Bul Psikol. 2019;27(2):148.

6. Atmojo DWT. Kontribusi Perilaku Game Online Terhadap Motivasi Belajar siswa SMA. Cognicia [Internet]. 2019;7(4):527-38.

7. Suryana OA, Supardi KIK. Desain Media Permainan Edukasi Berorientasi ChemoEdutainment Pada Pembelajaran Kimia Sma. Chem Educ [Internet]. 2018;7(2):46-53.

8. Hardini A. Pengaruh Penggunaan Crossword Puzzle Pada Pembelajaran Kooperatif Tipe Teams Games Tournament Terhadap Hasil Belajar Peserta [Internet]. Uin Jakarta; 2019.

9. Syofiana N, Salastri R, Hermansyah A. Perbandingan Hasil Belajar Siswa Menggunakan Model Pembelajaran Kooperatif Tipe Make A Match dan Team Games Tournament (TGT) Pada Mata Pelajaran Kimia Di Kelas X IPA MAN 1 Kota Bengkulu. Pendidik dan Ilmu Kim [Internet]. 2018;2(2):122-31.

10. Hanafi. Konsep Penelitian R \& D Dalam Bidang Pendidikan. Saintifika Islam J Kaji Keislam [Internet]. 2017;4(2):130.

11. Ramli M. TSRD Sebagai Pendekatan Alternatif Penelitian Pengembangan Inovasi Pendidikan : Sebuah Kajian Reflektif. In: Seminar Nasional Pendidikan FITK UIN Syarief Hidayatullah Jakarta. Jakarta; 2019.

12. Riduwan. Metode dan Teknik Menyusun Tesis. Bandung: Alfabeta Press; 2010.

13. Ridwan dan Sunarto. Pengantar Statistika Untuk Penelitian Pendidikan, Sosial, Ekonomi, Komunikasi, dan Bisnis. Bandung: Alfabeta Press; 2013.

14. Sumartono A, Luthfi A. Pembuatan Game Edukasi Platformer Perjalanan Mimpi Alfi Menggunakan Construct 2. Tetrahedron Lett. 2014;55:3909.

15. Verawati, Enny Comalasari. Pemanfaatan Android Dalam Dunia Pendidikan. In: Prosiding Seminar Nasional Pendidikan Program Pascasarjana Universitas Pgri Palembang 03 Mei 2019. 2019. p. 617-27.

16. Sriadhi, Restu R, Sidabutar UB, Dalimunthe A. The assessment model of multimedia learning feasibility. In: Global Conferences Series : Scineces and Technology [Internet]. Medan: Redwhite press; 2019. p. 17-21.

17. Ismail MUHI. Pemberian Rangkuman Sebagai Strategi Pembelajaran. Form J Ilm Pendidik MIPA [Internet]. 2011;1(1):48-57.

18. Nurhayati S, Mahatmanti FW, Khodijah FD. Keefektifan Pembelajaran Berbasis Question Student Have Dengan Bantuan ChemoEdutainment Media Key Relation Chart Terhadap Hasil Belajar Siswa. J Inov Pendidik
Kim [Internet]. 2011;3(1):1-1.

19. Saputri DY, Rukayah RR, Indriayu MI. Integrating Game-based Interactive Media as Instructional Media: Students' Response. J Educ Learn. 2018;12(4):638.

20. Iqbal M, Yusrizal, Subianto. Perencanaan Media Permbelajaran Aplikasi Pokok Bahasan Fluide Statis Untuk Siswa SMA. 2016;148:148-62.

\section{SUPPLEMENTARY FILES}

Penulis juga melampirkan media-media lainnya berupa gambar-gambar tangkapan layar dari permainan yang telah dikembangkan. Lampiran ini dapat diakses pada laman supplementary files. 